\title{
Rewriting the History through the Standpoint of Margin: A Rereading of B.P. Koirala's Atmabrittanta
}

Yog Raj Lamichhane

\section{https://doi.org/10.3126/litstud v29i01.39616}

\begin{abstract}
Atmabrittanta is a unique and transcribed autobiography of B. P. Koirala - a thinker and a statesman. Rewriting the history from the standpoint of margin is the prime issue of this work. It includes mainly painful, romantic, adventurous and even terrible anecdotes of different people which took place for the establishment and reactivation of democracy and pitiless plot against it. Those events which were historically marginalized and excluded in history are included in Atmabrittanta. The interim impulse of truth and power as well as the formation of discourses are scrutinized through some selective happenings. B. P. Koirala highlights the contemporary marginal issues and illustrates how the ink of authority is abused to craft one-sided and monolithic history. In this way, the text becomes the common experience of general people beyond author's journey of life and contradicts the mainstream history with full testimony of rebel. All these issues that walk off through the narrative make the autobiography more political than personal.
\end{abstract}

\section{B. P. Koirala and His Writing}

"Every man's life", remarked Dr Johnson "should be best written by himself" (qtd in Guha-1). This statement valorizes the role of autobiography. That auto writing is an excellent method to express the deep core of life. The text Atmabrittanta captures diverse aspects of contemporary Nepali society and questions on any form of domination. The constructed truth of Rana and fabricated history of Panchyat are directly countered by the text with full testament of rebel which makes it more political than personal. On the surface level the text includes the author's and his family story, but on deeper level it includes the collective life journey of general people with their common experience. The text also visits the major incidents and accidents of Nepal from 1920s to 1970 s. On the discussion of his strong writing capability especially on Narendra Dai, Sajha Prakashan says:

The writing style, use of language, structure of the sentence and art of creation are very unique and enchanting then his contemporaries who think literature is higher subject than the politics. (My Translation I)

While Koirala is taken as one of the most magical political leader, he is also one of the most well-read writers of Nepali literature. He wrote short stories and novels and even some poems. He was a perfect surgeon of women minds, which was beyond the chief concern and delivered the complex concepts. The study and the analysis of human mind which was formally started by Sigmund Freud were first practiced in Nepali literature by B.P. Koirala. In his stories, the emphasis simply goes to the role of Libido in human life as Nepali disciple of Sartre and Camus.

Shiva Adhikari, one of the prominent writer and critic of Nepali literature 
recognizes on B. P. Koirala that:

There are merely remaining words which are left to write about B.P. Koirala. After Buddha on the forename of one Nepali that many words are not used for any other. He is 'Sandaju' of all Nepali, this word symbolically echoes of people's life, cultural consciousness and political awareness. (My Translation 1)

Two historical periods are delivered by the text - the fall of British colonialism in India and closing stages of Rana oligarchy in Nepal. It clearly represents the consequence, how Nepal escaped from the hot pan in form of Rana regime but underwent upon fire in the form of direct rule of king in the name of Panchyat.

A Nepali writer Kanak Mani Dixit who is also the translator of Atmabrittanta into English outlines B. P. as, "Master story teller" (Vii). The narrated recollections into a microphone provide that he is not only a prominent story writer but also a perfect story teller.

\section{Visions and Views against the Ink of Authority}

New Historicism argues for the contexture of all human thought and activities. It claims no non-historical vantage point for judging such thought or activities. New Historicist mainly emphasizes the historical and cultural provision of the production. It blurs the hierarchy which privileges either the literary text over non literary text as new criticism or the non-literary text like history over literary as the old historicism. The New Historicism rejects the autonomy of text as well as the author and establishes inseparable relation to historical contexts.

French Philosopher, Michel Foucault's idea of discourse, power, truth, knowledge etc are building-blocks for New Historicism. It always seeks to find examples of power and how it dispersed within the text. According to Foucault that, "truth is not outside power" (133). New Historicist critic, Luis Montrose in his essay 'Professing the Renaissance: The Poetics and Politics of Cultures' establishes New Historicism as 'a reciprocal concern with historicity of the texts and the textuality of histories. In his article New Historicism Louis Montrose further attempts to clarify his idea in the following way:

The post structuralist orientation to history now emerging in literary studies I characterize chiastic ally, as a reciprocal concern with historicity of texts and the textuality of histories. By the historicity of texts, I mean to suggest the historical specificity, the social and material embedding, of all modes of writing including not only the texts that critics study but also the texts in which we study them; thus, I also mean to suggest the historical, social and material embedding of all modes of reading. (410)

A prominent critic Hayden White talks about the nature of language and narrative which are full of complex set of symbols, icons, allegory and so many other literary devices. So, historical writings cannot carry the objective truth. In this side White mentions:

All historical narratives presuppose figurative characterization of the events they purport to represent and explain. And this meant that historical narratives, considered purely as verbal artifacts, 
can be characterized by the figurative discourse [. . . ] language itself provided in the fore principal modes of figurative representation: metaphor, metonymy, synecdoche and irony. (404)

Literary work is no more objective and it can never escape social and cultural existence of the time. Lois Tyson in her book Critical Theory Today tries to show how New Historicism advocates the equal footing by blurring the hierarchy. He says, "Traditional historicism tended to ignore to marginalizes private life as subjective and irrelevant, New Historicism tries to compensate for this omission by bring issue concerned with private life auto the foreground of historical inquiry" (289). Similarly Wilfred L. Guerin in A Handbook of Critical Approaches to Literature talks about the raw ideas for the establishment of New Historicism and its key characteristics. He opines:

Michael Warner phrases New Historicism's motto as "the text is historical, and history is textual." Frederic Jameson insisted, "Always historicize! (The political unconscious) As a return to historical scholarship, New Historicism concerns itself with extra literary matters - letters, diaries, films, painting, medical treatieslooking to reveal opposing historical tensions in a text. (283)

In this sense, New Historicism undermines the concepts of transcendental truth and erases the dividing lines between history and literature. The present study is going to apply New Historicism in B.P. Koirala's Atmabrittanta which will play a remarkable role to study the text linking with its contexts which represent those different aspects of contemporary society. The autobiography - Atmabrittanta - revisits and rewrites the histories of the contemporary society from different standpoints.

\section{Rewriting the History through the Standpoint of Margin}

The revolutionary document of the $20^{\text {th }}$ century, Atmabrittanta represents the multidimensional accounts of protest. It is the cycle of exile to jail and jail to exile at personal level and common experience of struggle to establish freedom and equality as social level.

B. P. Koirala's text, Atmabrittanata captures the diverse aspect of contemporary Nepalese culture and society with the comments to mainstream history. It can be seen as a step of never ending re-composition of history and a challenge that blurs the distinction between text and context. Panchayat account of official history has been questioned and undermined by this autobiography Atmabrittanata. B.P.'s attempt to redraw the history encourages establishing multiple truths. All these make the text more political then personal. Against the idea of traditional historians, Atmabrittanata explores the socio-economic relation of state revolutionary journey and suffering of common Nepalese people.

The alternative version of Nepali history -Atmabrittanta- brings those sufferings of marginalized and suppressed people which were kept inside an underground chamber by power holders. All inclusive genealogical notions of the text counter those discourses which were established by ruler through the power of gun as well as the ink of pen. Many incomplete chapters of the Nepalese official history can be completed by relating the text with its context. In the beginning chapter of the autobiography B. P. states:

During the long period I spend in jail, with time on my hands, I 
did attempt to write about myself a couple of times. In doing so, I tried to describe the social and political system of the day. I found that I was writing more about other than about myself. (1)

Every text must be studied with its historical context which never let to be an authentic past. Individual perspective to history sweeps the idea of singular and absolute truths. That impossibility of authentic past sometime shaped by language too and has dialectical relationship with past and present. Those kinds of idea are classified through these lines:

I found Marxist philosophy revolutionary, but had become disenchanted with some aspects of the communist movement. For there, was the reality of the national movement of India in which my entire family had been engaged [. . .] my father an active participant. It was nothing, that it was being masterminded by the British themselves, and that Gandhi was an unknowing against of the British. I was also influenced by Trotsky's internationalism. I was certainly influenced by Marxist, but the communist party stopped exerting its pull on me. (19)

Every action is guided by will to power. One just wants to hold power and seems interested to dominate other to establish own monopoly. Mainstream history only glorifies those people who are in authority and reality is always kept inside a dark chamber. That kind of truth which is created by the relation of power, changes when system changes. The omnipresence nature of power can be seen with the analysis of the power of the king and B.P. King seems superior to prime minister in other looking but the power of prime minister was not less than the king inside. That can be studied through the following rows:

"All I have done is expressed simple criticism."

"Your majesty cannot express simple criticism if they came across as an attack against government."

He replied, "Okay then if I make any further mistakes, you can come to this room, take off your shoe and beat me with it. But please do maintain my dignity outside". (249)

One day king Mahendra offered a car to B.P. Koirala but Koirala rejected. By offering a car in one side the king's intention was to grab power from him. The following extract gives the hidden motive of king Mahendra:

He said, "Still [. . .] in case I would like to bring you a memento or something? Others have asked me for car. Shall I present you with a car?" [. . .] the morning of the thirds day after that meeting, rumor started flying about furious. The air was thick with talk that the king was about to act. (248-49)

The car was not the symbol of friendship but a form of temptation. The king had a honey tongue and a heart of gall together. It was a background of his future action against democracy. The cruel memento is memorable till now in Nepali politics as a black day. The productions of discourse and power struggle are related concepts. Discourse gives the birth of power and that ultimate generates knowledge. This power and knowledge are weapons to rule. And, the ruling class people, who are in power creates history in their favor. Minorities are not included. Like the issues of 'sexuality' and 'madness' in Atmabrittanta, we can get a subject- 'adultery'. An uncle of B.P. Koirala had done fourth marriage 
with a beautiful daughter of a Tantrik called Laxmi Kanta. The husband was old and the wife was still young. At last, she left him and started to live at her father's house in Calcutta. She was co-habited with the husband of her elder sister, while meeting with B.P. and his father she says:

"I will not go back. I have left him, and have now chosen my partner. I am living with my elder sister's husband, and find this more self respect than remaining a wife to someone forcefully. That, I consider adultery / byavichar where as here I have voluntarily accepted my sister's husband as my own. This is much more respectful for a woman than to suffer through a forced marriage." I was hit hard by that episode; byavichar means to live unwilling with someone, at least which was her definition of the term. My father was left speechless, and he had no answer. (52)

Unstable meaning is created by central human activity and discourse. Meaning of adultery is not fixed which is always changing. Here, B.P. Koirala's aunt took force and will to define adultery. The forceful living with husband is adultery for her. That is her interpretation. That definition was enough to make speechless. The action which is done voluntarily never falls under adultery in her definition. Her self-respect is linked with her meaning of byavichar. And, those discursive practices which transfer and change meaning of a same action in different contexts.

Atmabrittanta is genealogical version of history. It analyses the accidents which are historical but are not included in mainstream history. B.P. alters the linear history and writes about the struggles of marginalized people. The progressive account of heterogeneous ideas- Atmabrittanta -counters the monolithic and homogeneous mentality. This autobiography represents the marginalized and suppressed side which are rejected and neglected by so called formal and official historians. The revolt had taught a lesson to brutal ruler and established the voice of marginalized people when it was extended over Nepal. Laborers were highly exploited in Nepal and they had no legal rights before 1947. Trade Union Rights was unheard subjects for them, that discrimination over laborers is depicted by Atmabrittanta. Such situation was there in the case of laborer which can be clearly seen through following lines:

The laborers there had no right whatsoever, so the mill owner were able to do as they pleased. Girija and the other worked as clerks in the Jut mill [. . .] the demands put forward by the strikers included the rights to form a trade union [. . .] this was the first- ever political action on Nepali soil. It took the whole country, and led to welcome reaction from all over. (39)

The narrated official history sometime overstates the common role of the ruler and sometime understates the suffering, pain and tears of common people and their contributions. But, Atmabrittanta represents the past as it is. The truth is not always same. The flitting nature of truth is contextual and that conceptuality can be clearly seen by the two activities which were done by B.P. Koirala. About that, B. P. says, "In the context of world war, it was British imperialism which was fighting against Hitler. Within Europe, the British were alone in effectively confronting Germany. We hoped Hitler's defeat thought wishing for the 
departure of the British form India" (215).

The meaning of any text or verbal artifact can't be given meaning only through outer expression as self sufficient and autonomous. Therefore, personal intentions and response should be analyzed minutely to grasp the correct meaning. If the expression of Tulsi Giri is studied, it becomes clear:

Tulsi Giri demanded of our jailers, "We need the king's speech." Obviously the idea was to have me study it. We had been arrested at noontime and the king had made an announcement at three o' clock. Tulsi Giri shouted at the guards, "We have not seen the declaration! We want to study it!" He was exhibiting no fear whatsoever because, after all he was in with the king in all this. (256)

There is no any transcendental truth. The general traditional concept that commoner always goes to knock the door of palace. But the text unveils an event and shows the opposite picture that the crown prince Mahendra goes to ring the door bell of a representative of commoner- B.P. Koirala. Here is the short description of this moment.

One evening he dropped in unannounced [. . .] the crown prince arrived at such a time, without notice. A man came into say that the crown prince was waiting downstairs [. . . I came down and asked him, "Your Highness what bring you here without notice? He said, "I am about to resign as crown price. I will become a commoner." [. . .] "There is someone I wish to marry, my sisterin-law. My father refuses to allow it." [. . .] "Please try and resolve this matter quickly." $\mathrm{He}$ said, and left. (237-38)

Old traditional history is broken here by the activities of Mahendra and his language. The ideas of the circulation of power and instability of power are proved. Monolithic and singular history is displaced by the heterogeneous reconstruction. The traditional history which is fabricated by authority is revisited by the text, by narrating the event- the presence of crown prince in the door of commoner by requesting to solve the family problem of palace.

The exercise of king went like water on sand and agony remained. The source of that discourse about corruption is will to power. The power is operated through discourse and that can be seen in every institution. No discourse is out of language. In this purpose language doesn't remain only language in textual use. The meanings which are given by codified language have nothing to do. This idea is shown in Atmabrittanta in this way:

Another matter we discussed was that border issue. On that he signified that there as no great problem. "Let Mount Everest remain a common summit, and let us call it a friendship summit," he suggested. I didn't agree to that. I said, "But this falls within our country. How can we term it common?"

He said, "But you don't even have a name for it in your language, and you call it, "Mount Everest". (227)

Mao is creating a discourse about Mt. Everest. It is not matter of having a Nepali name or not, for it is sure that it lies in Nepali Geography.

The so-called historians think themselves as the reporters of objective 
truth. But there is impossibility of objective fact in history. The concepts like civilization and un-civilization, importance and unimportance etc are strongly influenced by the way of interpretation and presentation. B.P. Koirala's absence in New York airport to great Jawaharlal Nehru seems relevant here:

I remember an incident from a couple of days after I arrived in New York. Jawaharlalji had arrived, and Menan was insisting that we go to great him, which put me in a spot. Menan said, "He is your good friend, what the difficulty in this? This is not the matter of protocol." However, I decided that the matter would indeed raise eyebrows, Nepal's prime minister going to welcome India's prime minister in New York. I did not go, and do not know what meaning they ascribed to that. To begin with they sound never have made that suggestion. (234)

Our selfhood and subjectivity is shaped by our culture and politics. Individual nature and culture are important components of that type of shaping. Meaning lies only in interpretations. The autobiographical text -Atmabrittantagives overall analysis of the society and breaks the pillars of singular human identity. The ideas which was marginalized, rejected and hesitated to express be taken in front side through the text. When diplomatic relation was established with Israel, the meeting of the ambassador of six Arab countries with B.P. Koirala presents such overall representation.

The delegation was led by Ali Al - Feki, the ambassador of Egypt who traveled with his wife. He made his protest about the establishment of ties with Israel, but as soon as I presented my point of view, he said, "We are protesting in our official capacity. We know your line we have a quarrel with Israel, which you do not" that was his suggestion is private. We got along well, and his wife found a lot in common with Sushila. We all spoke about personal matters, such as about birth control, how many children we had, and about birth control pills. She even left some pills for Sushila. (236-37)

The heterogeneous mixture of politics and pills subvert the motion and notion of the linear history. It is an inclusive nature of Atmabrittanta. The process like reinterpretation and revaluation are always possible here. That type of history is written which is beneficial for ruler and that that history always twists the truth and sings the songs of power. Invocation is done there. All those techniques are applied to create hierarchy and to extend the gap. But B.P. Kiorala's efforts are just opposite to those methods. He just wants to blur the hierarchy and fill the gaps which are between rulers and ruled. B. P. Koirala action and writing depict the pictures of equality in this way:

It was not possible to sit normally. There was space for just one leg. So, I crossed my legs. As I did so, it turned out, one of my shoes pointed towards the monarch. [. . . I I felt it was important for the people who had been kept forcibly down by the kings to be shown thought such action that we were now equals that we can indeed sit on the some couch. So, that was also on effort on my part to sand a massage even though. (149) 
Atmabrittanta is not only the alternative version of history. Even context is textualized through the publication of this autobiography. Specially, the relation between base and super structure and socio-economic context are represented with great interest while discussing about the land reformation to a delegation in prime minister's residence. B.P. Koirala describes:

Meanwhile, the kings grant audience to any delegation that came to see him, be they land owners or anyone else. They would then feel energized and come to me [. . .] you should know that I am only planning to wrest your land away from you, not to chop your heads off. If any other extremist group takes power that is what they would do. You might have seen in the world. [. . .] Heads have rolled. I am not trying to wrest away your property violently. (243)

Any text can never cross its own time and cannot transcend the cultural, economic and ideological set up by the views of the delegation and the logics which are given by B. P. Koirala to convince them in his side- progressive taxation and ceiling. The ideology of land owners and the culture of a democratic socialist are shown soundly. Atmabrittanta breaks the hierarchy between high and low and good and bad culture as well as thinking. B.P. says in this context:

I believe that if a revolutionary is to conduct a revolution, then there should be no hesitation in raising money from any source. The only point is that the assistance should be provided without conditions. If support comes without conditions it is okay to take it. I believed that because of Nepal's Pro-Chinese and AntiIndian attitude, under certain circumstance it was possible to use India, the same way that in Russia Lenin used Germany. [. . .] according to the Hindu Shastra, gold is pure [. . .] the important thing is the use of money is put to. (294)

B. P. has no hesitation whether the money is white or black. It is the matter that how it is used. The real meaning is linked with its utilization. Money in itself carries no meaning. Application comes to establish meaning. In that case, here, B.P. was going to use for revolution which was compulsory for freedom and democracy. In this text B. P. highlights the contemporary marginal issues and erases the confusion of mainstream history. The socio-cultural situations of Nepal are disclosed. The text interestingly represents the trap of discourses which are used to generate power. The changing characters of Indian leaders also establish the idea of subjectivity and unstable truth. On this way B. P. kills two birds with a single stone- writing own biography and writing history.

\section{Conclusion}

B.P. Koirala's late life recollections- Atmabrittanta- provides surprising sight to gaze the history. Atmabrittanta itself is the study of the national and international conspiracy and discourses which were plotted and formed under the umbrella of hegemony against the will and freedom of Nepalese people. Power is the child of discourse and that has very diminutive life. Continuous reincarnation happens there but always in different forms. All those seem like illusions. The autobiography clears that how the ink of authority is applied to write the invocation of ruler. Historians write the history as a form of worship to the ruler resembling a songster sings a song following the choice of listener. So, that type 
of history is only dedicated to power. The narrated official history overstates the common role of rulers and understates the suffering, throbbing and cry of common people. On the name of countering the mainstream history, the latest inclusive edition of true history- Atmabrittanta- doesn't argue for the nothistorical past. It never encourages one to escape the history and doesn't recommend vanishing into void. Thus, the autobiography of a thinker and a statesman opines addition and deduction which are addictive weapons to fight against the one-sided and exclusive history of Rana and Panchayat. All those destabilizations of official history erect an inclusive and open-ended true history as a form of antithesis.

\section{Works Cited}

Adams, Hazard, ed. Critical Theory since Plato. Forthworth: Harcourt, 1992.

Adhakari, Shiva. Forewords. Babu, Ama ra Chhora. By (B)ishweshwor (P)rasad Koirala. $5^{\text {th }}$ ed. Lalitpur: Sajha Parkashan. 2004.

Dixit, Kanak Mani. Translator's Note. Atmabrittanta. By (B)ishweshor( P)rasad Koirala.Lalitipur: Jagadamba Publication, 2001.v-viii.

Foucault, Michael. "Nietzsche, genealogy and history." The Foucault Reader. Ed. Paul Rainbow. Harmondsworth: Penguin, 1984. 76-100.

Guerin, Wilfred, L. et al. eds. A Handbook of Critical Approaches to Literature, $5^{\text {th }}$ Ed. New York: Oxford University Press, 2005.

Guha, Ramchandra. "Permanent Rebellion: The Story of B.P. Koirala." Hindu 29 July 2001. <http:// www. hinduonnet.com/2001/07/29/stories/51290171. htm>

Koirala, B. P. Atmabrittanta: Late Life Recollections. Trans. Kanak Mani Dixit. Lalitpur: Jagadamba Publication 2001.

Koirala, Bisheshwor Prasad. Publisher's Note. Narendra Dai. $7^{\text {th }}$ ed. Latipur: Sajha Prakashan. 2006.

Lois, Tyson. Critical Theory Today. New York: Rutledge, 2006.

Montrose, Louis, "The New Historicism." Redrawing the Boundaries: The

Transformation of English and American Literary Studies. Eds. Stephen Greenblatt and Giles Gunn. New York: MLA, 1991. 392- 418.

White, Hyden. "Introduction to Metahistory." Literature in the Modern World. Ed.

Dennis Walder. Oxford and New York: Oxford University Press. 2004. 398-409. 